\title{
Anti-tumor effect of bisphosphonate (YM529) on non-small cell lung
} cancer cell lines

\author{
Ryuichiro Koshimune*1, Motoi Aoe ${ }^{1}$, Shinichi Toyooka1 ${ }^{1}$, Fumikata Hara1, \\ Mamoru Ouchida ${ }^{2}$, Masaki Tokumo ${ }^{1}$, Yoshifumi Sano ${ }^{1}$, Hiroshi Date ${ }^{1}$ and \\ Nobuyoshi Shimizu ${ }^{1}$
}

Address: ${ }^{1}$ Department of Cancer and Thoracic Surgery, Graduate School of Medicine, Dentistry and Pharmaceutical Sciences, Okayama University, 2-5-1 Shikata-cho, Okayama city, Okayama 700-8558, Japan and 2Department of Molecular Genetics, Graduate School of Medicine, Dentistry and Pharmaceutical Sciences, Okayama University, 2-5-1 Shikata-cho, Okayama city, Okayama 700-8558, Japan

Email: Ryuichiro Koshimune* - koshiryu16@hotmail.com; Motoi Aoe - motoiaoe@md.okayama-u.ac.jp; Shinichi Toyooka - s_toyooka@nigeka2.hospital.okayama-u.ac.jp; Fumikata Hara - fumi7hara@ hotmail.com;

Mamoru Ouchida - ouchidam@md.okayama-u.ac.jp; Masaki Tokumo - masakitoku@yahoo.co.jp; Yoshifumi Sano - ysano@md.okayamau.ac.jp; Hiroshi Date - hdate@md.okayama-u.ac.jp; Nobuyoshi Shimizu - dr_lung@md.okayama-u.ac.jp

* Corresponding author

Published: 12 January 2007

BMC Cancer 2007, 7:8 doi:10.1186/147|-2407-7-8
Received: 24 September 2006

Accepted: 12 January 2007

This article is available from: http://www.biomedcentral.com/I47/-2407/7/8

(c) 2007 Koshimune et al; licensee BioMed Central Ltd.

This is an Open Access article distributed under the terms of the Creative Commons Attribution License (http://creativecommons.org/licenses/by/2.0), which permits unrestricted use, distribution, and reproduction in any medium, provided the original work is properly cited.

\begin{abstract}
Background: YM529 is a newly developed nitrogen-containing bisphosphonate (BP) classified as a third-generation BP that shows a 100 -fold greater potency against bone resorption than pamidronate, a second-generation BP. This agent is, therefore expected to be extremely useful clinically for the treatment of osteoporosis and hypercalcemia. Recently, YM529 as well as other third-generation BPs have also been shown to exert anti-tumor effects against various types of cancer cells both in vitro or/and in vivo. In this study, we investigate the anti-tumor effect of YM529 on non-small cell lung cancer (NSCLC).

Methods: Direct anti-tumor effect of YM529 against 8 NSCLC cell lines (adenocarcinoma: H23, $\mathrm{HI} 299$, NCl-HI819, NCl-H2009, H44, A549, adenosquamous cell carcinoma: $\mathrm{NCl}-\mathrm{H} / 25$, squamous cell carcinoma: $\mathrm{NCl}-\mathrm{HI} 57$ ) were measured by MTS assay and calculated inhibition concentration $50 \%\left(\mathrm{IC}_{50}\right)$ values. YM529 induced apoptosis of $\mathrm{NCl}-\mathrm{HI} 8 \mathrm{I} 9$ was examined by DNA fragmentation of $2 \%$ agarose gel electrophoresis and flowcytometric analysis (sub-G, method). We examined where YM529 given effect to apoptosis of NSCLC cells in signaling pathway of the mevalonate pathway by western blotting analysis.

Results: We found that there was direct anti-tumor effect of YM529 on 8 NSCLC cell lines in a dose-dependent manner and their $\mathrm{IC}_{50}$ values were 2.1 to $7.9 \mu \mathrm{M}$ and $\mathrm{YM} 529$ induced apoptosis and $G_{1}$ arrest cell cycle with dose-dependent manner and YM529 caused down regulation of phospholyration of ERKI/2 in signaling pathways of NSCLC cell line ( $\mathrm{NCl}-\mathrm{H} / 819)$.

Conclusion: Our study demonstrate that YM529 showed direct anti-tumor effect on NSCLC cell lines in vitro, which supports the possibility that third-generation BPs including YM529 can be one of therapeutic options for NSCLC.
\end{abstract}




\section{Background}

Lung cancer is the leading cause of death from cancer worldwide. Approximately $80 \%$ of lung cancers can be histologically classified as non-small cell lung cancers (NSCLCs). The majority of patients presents with locally advanced $(37 \%)$ or metastatic $(38 \%)$ disease at the time of diagnosis [1]. Despite advances in chemotherapy, the average 5-year survival rate of the patients with advanced NSCLC remains extremely poor [1]. Thus, newer agents must be developed to establish an effective therapeutic strategy against NSCLC.

Bisphosphonates (BPs) are structural analogues of pyrophosphoric acid, which is a biomedical component. Several studies have shown that BPs exert direct anti-tumor effects on a variety of human tumor cell lines (myeloma, breast, prostate, pancreas) in vitro in a concentration- and time-dependent manner [2-13]. BPs have a common basic structure and different substituents at the one of two covalentlybounded side-chain attached to the germinal carbon, which strongly influence their pharmacologic properties [14]. The so-called second- or third-generation BPs contain nitrogen and inhibit protein prenylation in osteoclasts to induce apoptosis [14-17]. YM529 (1Hydroxy-2-imidazo [1,2-a]pyridin-3-yl) ethylidene bisphosphonic acid monohydrate is a newly developed nitrogen-containing BP classified as a third-generation BP that shows a 100-fold greater potency against bone resorption than pamidronate, a second-generation BP. This agent is, therefore expected to be extremely useful clinically for the treatment of osteoporosis and hypercalcemia.

Recently, YM529 as well as other third-generation BPs have also been shown to exert anti-tumor effects against various types of cancer cells both in vitro or/and in vivo $[7,13,18-22]$. However, study that evaluated the effect of BPs including YM529 on NSCLC has been limited and the effect of zoledronic acid on only one cell line was examined [23].

In this study, we examined the effects of YM529 on 8 NSCLC cell lines to investigate the potential usefulness of YM529 as a therapeutic agent against NSCLC.

\section{Methods}

\section{Reagents and cell lines}

YM529 was kindly provided by Astellas Pharmaceuticals Co., Ltd. (Tokyo, Japan). YM529 was diluted in $10 \mathrm{mM}$ of concentration and stored at $-20^{\circ} \mathrm{C}$ for in vitro experiment.

Eight human NSCLC cell lines (adenocarcinoma; NCIH23, NCI-H1819, NCI-H2009, HCC44, A549, squamous cell carcinoma; NCI-H157, adenosquamous cell carcinoma; NCI-H125, large cell carcinoma; NCI-H1299, there are involved all type of NSCLC) were kindly provided by Dr. Adi F. Gazdar (University of Texas Southwestern Medical Center, Dallas, USA). All 8 cell lines were maintained at $37^{\circ} \mathrm{C}$ in a fully humidified atmosphere of $5 \% \mathrm{CO}_{2}$ in air as suspension cultures in RPMI-1640 medium (Sigma chemical co. St. Louis, MO) supplemented with $10 \%$ fetal bovine serum (FBS) and $100 \mathrm{U} / \mathrm{ml}$ penicillin and $100 \mu \mathrm{g} /$ $\mathrm{ml}$ streptomycin (Sigma chemical co. St. Louis, MO).

\section{Determination of cell proliferation}

Cell proliferation was determined by a modified MTS assay with CellTiter $96^{\circledR}$ AQueous One Solution Reagent (Promega, Madison, WI). NSCLC cells were seeded on 96well flat-bottomed tissue culture plates(Becton Dickinson, San Jose, CA) at a concentration of $5 \times 10^{3}$ cells/well with complete culture medium and allowed to adhere to the plate overnight. Then the cells were incubated in the presence of each concentration of 0 (control), $0.01,0.1,1$, $5,10,20,50,100,200 \mu \mathrm{M}$ of YM529 for another 72 hours at $37^{\circ} \mathrm{C}$ in a humidified atmosphere of $5 \% \mathrm{CO}_{2}$ in air. After treatment, $20 \mu$ l of CellTiter $96^{\circledR}$ AQueous One Solution Reagent were dropped into each well of plates. After 90 minutes incubation, the optical densities (OD) of these samples were directly measured using an Immuno Mini NJ-2300 (Nalge Nunc International KK, NY, USA) and reference wavelength of $490 \mathrm{~nm}$. The OD of control samples was regarded as 100 . Each condition was performed with 8 wells and each experiment was repeated twice. The anti-proliferative activities of YM529 are shown in terms of $\mathrm{IC}_{50} \mathrm{~s}$.

\section{Electrophoresis of DNA fragment}

NCI-H1819 cells were treated with concentrations 0 (negative control) and 10, $100 \mu \mathrm{M}$ of YM529 for 48 hours. As positive control, NCI-H1819 was incubated for 24 hours after UV light $\left(10 \mathrm{~mJ} / \mathrm{cm}^{2}\right)$ irradiation. Genomic DNA was isolated by digestion with proteinase $\mathrm{K}$ followed by phenol:chloroform (1:1) extraction and ethanol precipitation from cell lines and primary tumor [24].

DNA and DNA marker of TrackIt $1 \mathrm{~kb}$ Plus Ladder (Invitrogen co. Carlsbad, CA, USA) were separated on $2 \%$ agarose gels.

\section{Flow cytometric analysis of apoptosis}

Subconfluent NCI-H1819 cells were cultured in $60 \mathrm{~mm}$ dishes with concentrations 0 (control), 10 and $100 \mu \mathrm{M}$ of YM529 for 24 hours. Cells were trypsinized, fixed in $70 \%$ iced-cold ethanol, and stored at $-20^{\circ} \mathrm{C}$ for 72 hours. After fixation, cells were suspended in $100 \mu \mathrm{l}$ phosphate-citrate buffer ( $0.19 \mathrm{M} \mathrm{Na}_{2} \mathrm{HPO}_{4}, 4 \mathrm{mM}$ citric acid) and incubated for $30 \mathrm{~min}$ at room temperature and resuspended in $1 \mathrm{ml}$ of PBS containing $10 \mu \mathrm{g} / \mathrm{ml}$ of propidium iodide (PI) and $10 \mu \mathrm{g} / \mathrm{ml}$ of RNase A. The PI-stained cell samples were analyzed using FACSCalibur (Becton-Dickinson San Jose, 
CA) and data analysis for the population of cells in sub$G_{1}, G_{1}, S$ and $G_{2} / M$ phase of the cell cycle was performed with CELLQuest (Becton-Dickinson San Jose, CA). Cells undergoing apoptosis were determined as a percentage of cells with sub- $\mathrm{G}_{1}$ population.

\section{Western blotting analysis}

Subconfluent NCI-H1819 cells were cultured in $60 \mathrm{~mm}$ dishes with concentrations 0 (control), 10 and $100 \mu \mathrm{M}$ of YM529 for 24 hours. Equal amount of protein $(10 \mu \mathrm{g})$ were separated by SDS-PAGE and transferred to PVDF membranes. The membranes were probed with monoclonal anti-Ras (Becton Dickinson biosciences, San Jose, CA), goat polyclonal anti-unprenylated Rap1A antibody (Santa Cruz Biotechnology inc., Santa Cruz, CA), antiERK1/2 (Sigma chemical co. St. Louis, MO), anti-phospho-ERK1/2, anti-Akt, anti-phospho-Akt, $\beta$-actin (Cell Signaling Technology Inc., MA, US) antibodies, and then with goat anti-rabbit, goat anti-mouse and rabbit antigoat IgG-HRP coupled to horseradish peroxidase conjugated secondary antibodies (Santa Cruz biotechnology inc., Santa Cruz, CA), after which the membranes were developed by ECL Plus Western Blotting Detection Reagents (Amersham Biosciences UK Limited, Buckinghamshire, UK).

\section{Results}

\section{YM529 inhibited growth of NSCLC cell lines}

To evaluate the growth inhibitory effect of YM529 on NSCLC cell lines, we used the MTS assay and calculated the $\mathrm{IC}_{50}$ values. YM529 inhibited cell proliferation in a concentration-dependent manner in all the 8 cell lines (Fig. 1). The $\mathrm{IC}_{50}$ values for the 8 NSCLC cell lines ranged from 2.1 to $7.9 \mu \mathrm{M}$. Because YM529 inhibited the proliferation of NCI-H1819 most strongly among 8 NSCLC cell lines (Fig. 1), for following experiments, this cell line (NCI-H1819) was used as a model line.

\section{Induction of apoptosis}

To confirm that YM529 caused apoptosis, we examined the fragmentation status of genomic DNA in NCI-H1819 cells treated with drug (Fig. 2). DNA was extracted and electorophoresis was performed. As shown in Fig. 3, short fragments of DNA were observed in the cell cultures treated with 10 and $100 \mu \mathrm{M}$ of YM529, similar to the result in the positive control which was represented by NCI-H1819 cells exposed to UV light irradiation at $10 \mathrm{~mJ} /$ $\mathrm{cm}^{2}$ (Fig. 2).

\section{Cell cycle distribution}

To elucidate the molecular mechanism underlying the anti-tumor activity of YM529, we examined the cell cycle distribution in NCI-H1819 cells by flow cytometric analysis after PI staining. No significant changes in the $S$ and $G_{2} / M$ phase of the cell cycle was observed for any concen- tration of YM529. However, an increase in the percentage of cells in the $G_{1}$ phase was observed in a YM529-concentration-dependent manner (Fig. 3). While there were no significant changes in the population of cells in the sub$G_{1}$ phase in the cells subjected to no treatment or treated with 1 or $10 \mu \mathrm{M}$ of YM529 (4.2, 3.0, and $3.9 \%$, respectively), a significant increase in the population of cells in the sub- $G_{1}$ phase was observed in the cells treated with $100 \mu \mathrm{M}$ of YM529 (21.0\%) (Fig. 3). These results suggest that YM529 induced cell cycle arrest at the $\mathrm{G}_{1}$ phase and consequently stimulated apoptosis in the NCI-H1819 cell line.

\section{Down-regulation of anti-apoptosis}

To identify the molecules involved in the YM529-induced cell cycle arrest and apoptosis, we examined the protein expression status of members of the small GTP-binding protein related cascade that YM529 was assumed to inhibit in order to cause apoptosis. Western blotting analysis showed that anti-Ras or anti-unprenylated Rap1A antibody recongnized the unprenylation of Ras or Rap1A in a dose-dependent manner of YM529 (Fig. 4). In addition, the phospho-ERK1/2 protein was down-regulated by YM529 treatment. (Fig. 4). These results suggested that YM529 inhibited ERK1/2 pathway via inhibition of farnesylation and/or geranylgeranylation of GTP-binding proteins. There were no significant changes in the expression of either Akt or phospho-Akt in the cells.

\section{Discussion}

Our studies showed that YM529 directly inhibited cell proliferation in NSCLC cell lines. The $\mathrm{IC}_{50}$ values of YM529 for the 8 cell lines examined ranged from 2.1 to $7.9 \mu \mathrm{M}$. While the effects of third-generation BPs, including YM529, YM175 and zoledronic acid, have been examined in several kinds of human cancers, this is the first study to shown that the third-generation BPs may also be effective against NSCLC [9-13,22,23]. YM529 is as potent as zoledronic acid at inhibiting bone resorption in vivo, despite the difference in the substituent at the covalentlybounded side-chain. In relation to the effects of these agents on human cancer, YM529 and zoledronic acid have been reported to show similar cytotoxic effects against luekemic cell lines, with an $\mathrm{IC}_{50}$ value of 22-73 $\mu \mathrm{M}$ [19], which also indicates that the $\mathrm{IC}_{50}$ value of YM529 for NSCLC was lower than that for leukemic cell lines. Indeed, the $\mathrm{IC}_{50}$ value for leukemic cells in our study was similar to that reported previously, which also indicated that our assay was appropriate. In the case of lung cancer, the effect of zoledronic acid was examined against 12 small-cell lung cancer (SCLC) cell lines; it was shown that the agent exerted anti-proliferative effect in of the 8 cell lines with $\mathrm{IC}_{50}$ values in the range of $13-30 \mu \mathrm{M}$, whereas the remaining cell lines were resistant to zoledronic acid [22]. Taking into account this finding 

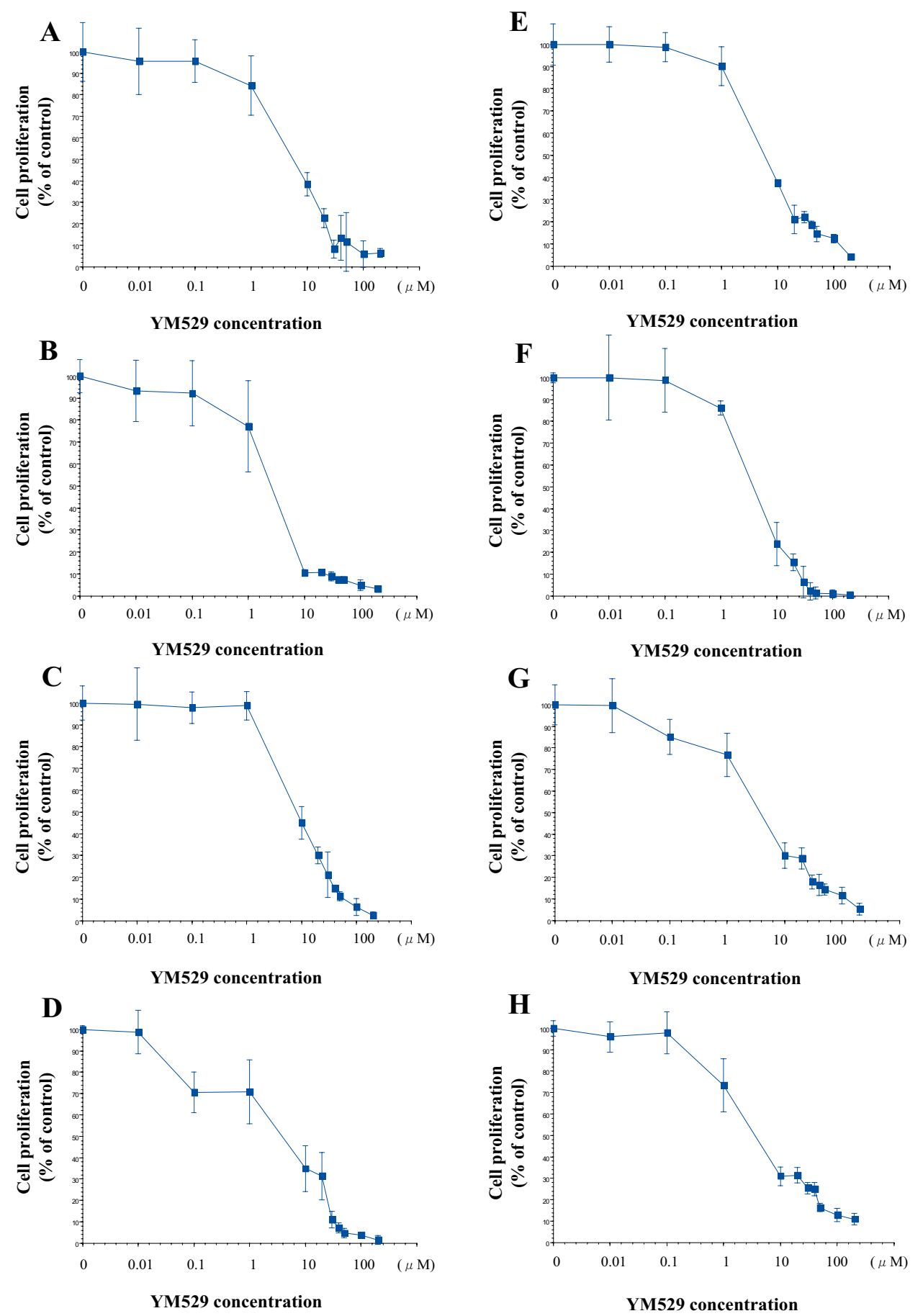

\section{Figure I}

Direct effect of YM529 on 8 cell lines of NSCLC cell lines H23 (A), HI299 (B), NCl-HI8I9 (C), NCl-H2009 (D), H44 (E), A549 (F), NCl-HI25 (G), NCl-HI $57(\mathrm{H})$. Cells were incubated with concentration of 0 (control), 0.0I, 0.I, I, 5, I0, 20, 50, I00 $\mu \mathrm{M}$ of YM529 for 72 hours exposure, and cell proliferation was determined by MTS assay. Date represent cell number during treatment relative to control untreated cells (100\%). The averages: bars, SD. 
M

NT

\begin{abstract}
Positive
Control
\end{abstract}

UV10,000J
YM529

$10 \mu \mathrm{M}$
YM529

$100 \mu \mathrm{M}$



\section{Figure 2}

DNA fragmentation induced by treatment of YM529 (I0, $100 \mu \mathrm{M})$ and UV irradiation. DNA of UV irradiation $\left(10 \mathrm{~mJ} / \mathrm{cm}^{2}\right)$ was positive control. DNAs of no treatment (negative control), positive control, treatment of $10,100 \mu M$ YM529 were fractionated through a $2 \%$ agarose gel and stained with ethidium bromide. Lane $M$ in panel is size markers.

with our own, it appears that third-generation BPs may be more effective against NSCLC than against SCLC.

In regard to the mechanism of action of nitrogen-containing BPs, including YM529, it is thought that they inhibit the activity of farnesyl diphosphate (FPP) synthase and geranylgeranyl diphosphate (GGPP) synthase which cause activation of FPP and GGPP, respectively. Since FPP and GGPP activation cause prenylation of small GTPbinding proteins including Ras resulting in anti-apoptosis, inhibition of their activation by YM529 induces cellular apoptosis [25-29]. Indeed, YM529 induced unprenylation of Ras and Rap1A resulting in down-regulation of ERK1/2 phosphorylation in NCI-H1819 cells despite absence of any effect on ERK1/2 expression.
Recent reports have shown that inhibition of the ERK1/2 pathway reduces cycline-CDK2 kinase activity and subsequent $\mathrm{G}_{1}$ arrest indicating apoptosis [30,31]. Our flow cytometirc analysis of the NCI-H1819 cell line confirmed the increase of the $\mathrm{G}_{1}$ population with YM529 treatment. Taking together these findings, it is speculated that YM529 exerts its anti-proliferative effect against NSCLC by induction of cellular apoptosis through the small GTP-binding proteins associated signal transduction pathway.

Several studies have indicated the usefulness of the combined use of BPs with other cytotoxic agents [12,22,32]. Matsumoto et al. reported that zoledronic acid augmented the anti-proliferative activity of paclitaxel, etoposide, cisplatinum, irinotecan and imatinib in SCLC cells 



\section{The population of cell cycle in NCI-H1819 (\%)}

\begin{tabular}{|l|c|c|c|c|}
\hline & C & YM529 $1_{\mu}$ M & YM529 $10_{\mu} M$ & YM529 $100_{\mu}$ M \\
\hline Sub-G1 & 4.2 & 3 & 3.9 & 21 \\
\hline G1 & 75.1 & 75 & 65.6 & 43.6 \\
\hline S & 8.4 & 10 & 8.7 & 17.3 \\
\hline G2/M & 12.3 & 12 & 21.8 & 18.1 \\
\hline
\end{tabular}

Figure 3

Cell cycle analysis of NSCLC cells treated with YM529. NCI-HI8I9 cells were stained with PI after 24 hours exposure of no treatment (control), I, $10100 \mu \mathrm{M}$ of YM529. There were analyzed by flow cytometry. DNA histgram of control (A), YM529 I $\mu M(B)$, YM529 $10 \mu M(C)$, YM529 $100 \mu M$ (D) were shown. The percentages of the cell population in the different phase (sub$G_{1}, G_{1}, S, G_{2} / M$ ) of cell cycle were analyzed by CELLQuest. Percentages of apoptosis were measured as sub- $G_{1}$ content of histogram. Similar results were obtained in three independent experiments.

[22]. In addition, cytotoxic agents, including cisplatin, gemcitabine, and taxol shown enhanced anti-tumor effect when combined with a farnesyltransferase inhibitor (FTI2148) or geranylgeranyltransferase inhibitor (GGTI2154) in mice bearing A549 cells [32]. Because YM529 is assumed to inhibit farnesylation and geranylgeranylation synthase as mentioned, combined treatment with YM529 and these cytotoxic agents may be a more effective treatment strategy than monotherapy in the case of NSCLC as well.

\section{Conclusion}

Our study demonstrated that YM529 showed direct antitumor effect on NSCLC cell lines in vitro and induced apoptosis and $G_{1}$ arrest cell cycle through down regulation of phospholyration of ERK1/2. These findings sup- port the possibility that third-generation BPs including YM529 can be one of therapeutic options for NSCLC.

\section{Competing interests}

The author(s) declare that they have no competing interests.

\section{Authors' contributions}

RK drafted the manuscript and carried out the experiment. MA conceived the study. ST managed the experiment and edited the manuscript. FH carried out western blotting. $\mathrm{MO}$ and MT carried out extracting DNA and electorophoresis for DNA. YS gave valuable advice for flow cytometric assay. HD and NS conceived the study and participated in its coordination. All authors read and approved this manuscript. 
YM529 concentration $(\mu \mathrm{M})$

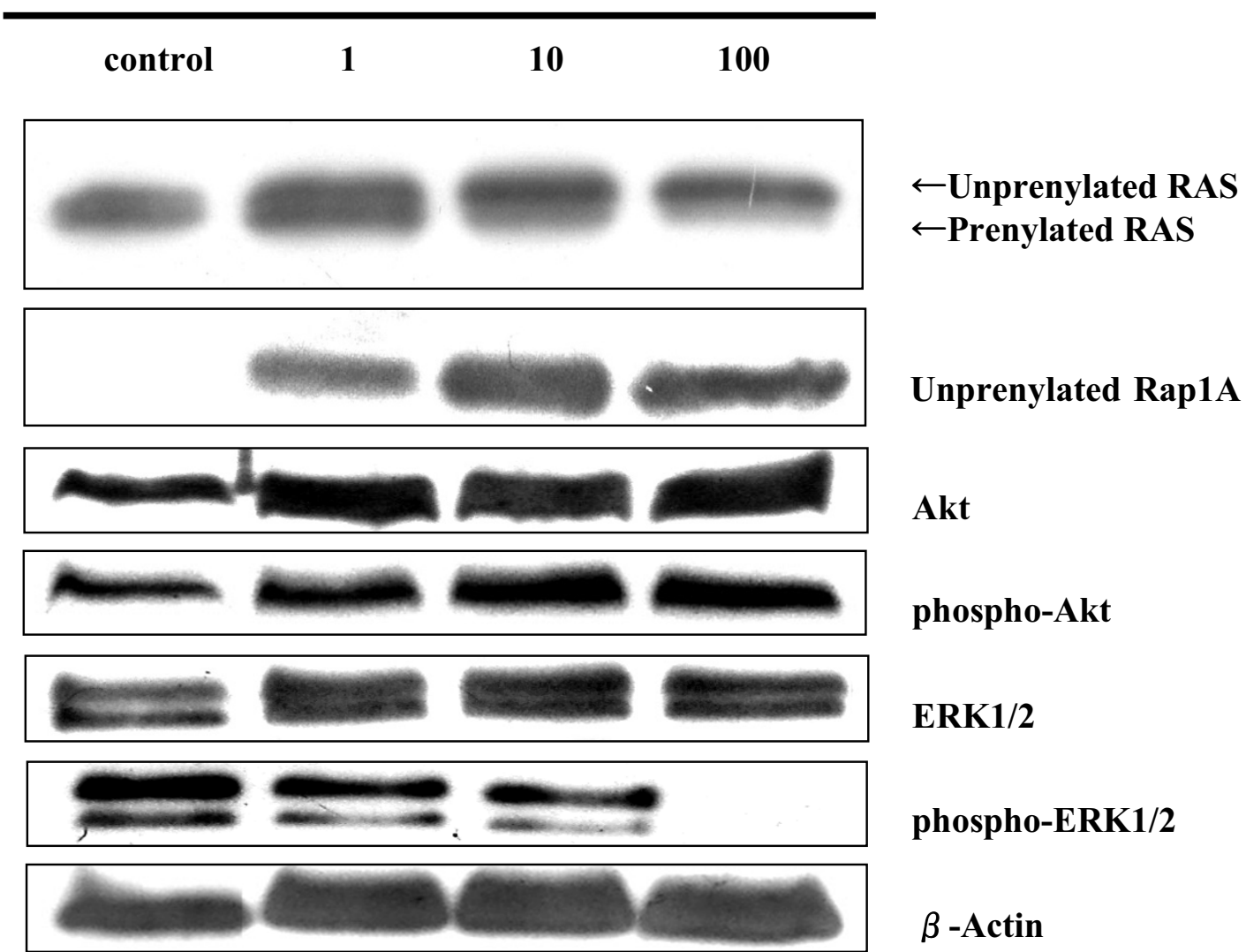

\section{Figure 4}

Concentration- course changes of Ras, RapIA, Akt, phospho-Akt, ERKI/2, phospho-ERKI/2 activation in NCl-HI8I9 cells treated with YM529 by using Western blot. Cells were incubated in CM with $10 \% \mathrm{FBS}$. Equal amounts of protein were loaded in each lane. $\beta$-Actin was used as internal control.

\section{Acknowledgements}

We thank Dr. Adi F Gazdar for providing 8 NSCLC cell lines and Astellas Pharmaceuticals for the supply of YM529. We also thank Mayumi Okada and Makiko Tabata for expert experimental assistance. This research is not funded.

\section{References}

I. Jemal A, Siegel R, Ward E, Murray T, Xu J, Smigal C, Thun MJ: Cancer statistics, 2006. CA Cancer J Clin 2006, 56(2): I06-I 30.

2. Shipman CM, Rogers MJ, Apperley JF, Russell RG, Croucher PI: Bisphosphonates induce apoptosis in human myeloma cell lines: a novel anti-tumour activity. $\mathrm{Br} /$ Haematol 1997, 98(3):665-672.

3. Shipman CM, Croucher PI, Russell RG, Helfrich MH, Rogers MJ: The bisphosphonate incadronate (YMI75) causes apoptosis of human myeloma cells in vitro by inhibiting the mevalonate pathway. Cancer Res 1998, 58(23):5294-5297.

4. Aparicio A, Gardner A, Tu Y, Savage A, Berenson J, Lichtenstein A: In vitro cytoreductive effects on multiple myeloma cells induced by bisphosphonates. Leukemia 1998, I2(2):220-229.
5. Derenne S, Amiot M, Barille S, Collette M, Robillard N, Berthaud P, Harousseau JL, Bataille R: Zoledronate is a potent inhibitor of myeloma cell growth and secretion of IL- 6 and MMP-I by the tumoral environment. J Bone Miner Res 1999, I 4(I 2):2048-2056.

6. Tassone P, Forciniti S, Galea E, Morrone G, Turco MC, Martinelli V, Tagliaferri $P$, Venuta S: Growth inhibition and synergistic induction of apoptosis by zoledronate and dexamethasone in human myeloma cell lines. Leukemia 2000, I4(5):84I-844.

7. Takahashi R, Shimazaki C, Inaba T, Okano A, Hatsuse M, Okamoto A, Hirai $H$, Ashihara $E$, Nakagawa M: A newly developed bisphosphonate, YM529, is a potent apoptosis inducer of human myeloma cells. Leuk Res 200I, 25(I):77-83.

8. Giuliani N, Pedrazzoni M, Passeri G, Girasole G: Bisphosphonates inhibit IL-6 production by human osteoblast-like cells. Scand J Rheumatol 1998, 27(I):38-4I.

9. Senaratne SG, Pirianov G, Mansi JL, Arnett TR, Colston KW: Bisphosphonates induce apoptosis in human breast cancer cell lines. Br J Cancer 2000, 82(8): |459-| 468.

10. Lee MV, Fong EM, Singer FR, Guenette RS: Bisphosphonate treatment inhibits the growth of prostate cancer cells. Cancer Res 200I, 6 I (6):2602-2608. 
II. Fromigue O, Lagneaux L, Body J]: Bisphosphonates induce breast cancer cell death in vitro. J Bone Miner Res 2000, I 5( I I ):22 I I-222I.

12. Jagdev SP, Coleman RE, Shipman CM, Rostami HA, Croucher PI: The bisphosphonate, zoledronic acid, induces apoptosis of breast cancer cells: evidence for synergy with paclitaxel. $\mathrm{Br} J$ Cancer 200I, 84(8): II26-II34.

13. Tassone $P$, Tagliaferri P, Viscomi C, Palmieri C, Caraglia M, D'Alessandro A, Galea E, Goel A, Abbruzzese A, Boland CR, Venuta S: Zoledronic acid induces antiproliferative and apoptotic effects in human pancreatic cancer cells in vitro. $\mathrm{Br} J$ Cancer 2003, 88(I 2): | 97|- | 978.

14. Widler L, Jaeggi KA, Glatt M, Muller K, Bachmann R, Bisping M, Born AR, Cortesi R, Guiglia G, Jeker H, Klein R, Ramseier U, Schmid J, Schreiber G, Seltenmeyer Y, Green JR: Highly potent geminal bisphosphonates. From pamidronate disodium (Aredia) to zoledronic acid (Zometa). J Med Chem 2002, 45(I 7):372I-3738.

15. Suri S, Monkkonen J, Taskinen M, Pesonen J, Blank MA, Phipps RJ, Rogers $M J$ : Nitrogen-containing bisphosphonates induce apoptosis of Caco-2 cells in vitro by inhibiting the mevalonate pathway: a model of bisphosphonate-induced gastrointestinal toxicity. Bone 200I, 29(4):336-343.

16. Chen T, Berenson J, Vescio R, Swift R, Gilchick A, Goodin S, LoRusso P, Ma P, Ravera C, Deckert F, Schran H, Seaman J, Skerjanec A: Pharmacokinetics and pharmacodynamics of zoledronic acid in cancer patients with bone metastases. J Clin Pharmacol 2002, 42(I I): I228-1236.

17. Sato M, Grasser W, Endo N, Akins R, Simmons H, Thompson DD, Golub E, Rodan GA: Bisphosphonate action. Alendronate localization in rat bone and effects on osteoclast ultrastructure. J Clin Invest 1991, 88(6):2095-2I05.

18. Cui N, Nomura T, Noma H, Yokoo K, Takagi R, Hashimoto S, Okamoto M, Sato M, Yu G, Guo C, Shibahala T: Effect of YM529 on a model of mandibular invasion by oral squamous cell carcinoma in mice. Clin Cancer Res 2005, I I (7):27 I3-27I9.

19. Segawa H, Kimura S, Kuroda J, Sato K, Nogawa M, Yuasa T, Yokota A, Hodohara K, Fujiyama Y, Maekawa T: The anti-leukemic efficacy of the third generation bisphosphonate ONO5920/ YM529. Leuk Res 2005, 29(4):45I-457.

20. Yuasa T, Nogawa M, Kimura S, Yokota A, Sato K, Segawa H, Kuroda J, Maekawa T: A third-generation bisphosphonate, minodronic acid (YM529), augments the interferon alpha/beta-mediated inhibition of renal cell cancer cell growth both in vitro and in vivo. Clin Cancer Res 2005, I I (2 Pt I):853-859.

21. Horie $N$, Murata $H$, Nishigaki $Y$, Matsui $T$, Segawa $H$, Nogawa $M$, Yuasa T, Kimura S, Maekawa T, Fushiki S, Kubo T: The third-generation bisphosphonates inhibit proliferation of murine osteosarcoma cells with induction of apoptosis. Cancer Lett 2006 , 238(I): III-II8.

22. Matsumoto S, Kimura S, Segawa H, Kuroda J, Yuasa T, Sato K, Nogawa M, Tanaka F, Maekawa T, Wada H: Efficacy of the thirdgeneration bisphosphonate, zoledronic acid alone and combined with anti-cancer agents against small cell lung cancer cell lines. Lung Cancer 2005, 47( I):31-39.

23. Tannehill-Gregg SH, Levine AL, Nadella MV, Iguchi H, Rosol TJ: The effect of zoledronic acid and osteoprotegerin on growth of human lung cancer in the tibias of nude mice. Clin Exp Metastasis 2006, 23(I): 19-31.

24. Herrmann BG, Frischauf AM: Isolation of genomic DNA. Methods Enzymol 1987, I 52:180-183.

25. Katz ME, McCormick F: Signal transduction from multiple Ras effectors. Curr Opin Genet Dev 1997, 7(1):75-79.

26. Bergstrom JD, Bostedor RG, Masarachia PJ, Reszka AA, Rodan G: Alendronate is a specific, nanomolar inhibitor of farnesy diphosphate synthase. Arch Biochem Biophys 2000, 373(I):23I-24I.

27. van Beek E, Pieterman E, Cohen L, Lowik C, Papapoulos S: Nitrogencontaining bisphosphonates inhibit isopentenyl pyrophosphate isomerase/farnesyl pyrophosphate synthase activity with relative potencies corresponding to their antiresorptive potencies in vitro and in vivo. Biochem Biophys Res Commun I999, 255(2):49|-494.

28. Neri A, Knowles DM, Greco A, McCormick F, Dalla-Favera R: Analysis of RAS oncogene mutations in human lymphoid malignancies. Proc Natl Acad Sci U S A 1988, 85(23):9268-9272.
29. Dunford JE, Thompson K, Coxon FP, Luckman SP, Hahn FM, Poulter $\mathrm{CD}$, Ebetino $\mathrm{FH}$, Rogers MJ: Structure-activity relationships for inhibition of farnesyl diphosphate synthase in vitro and inhibition of bone resorption in vivo by nitrogen-containing bisphosphonates. J Pharmacol Exp Ther 200I, 296(2):235-242.

30. Shintani S, Li C, Mihara M, Yano J, Terakado N, Nakashiro K, Hamakawa H: Gefitinib ('Iressa', ZDI839), an epidermal growth factor receptor tyrosine kinase inhibitor, up-regulates p27KIPI and induces GI arrest in oral squamous cell carcinoma cell lines. Oral Oncol 2004, 40(I):43-5I.

31. Di Gennaro E, Barbarino M, Bruzzese F, De Lorenzo S, Caraglia M, Abbruzzese A, Avallone A, Comella P, Caponigro F, Pepe S, Budillon $A$ : Critical role of both p27KIPI and p2ICIPI/WAFI in the antiproliferative effect of ZDI839 ('Iressa'), an epidermal growth factor receptor tyrosine kinase inhibitor, in head and neck squamous carcinoma cells. J Cell Physiol 2003, 195(I): I39-150.

32. Sun J, Blaskovich MA, Knowles D, Qian Y, Ohkanda J, Bailey RD, Hamilton AD, Sebti SM: Antitumor efficacy of a novel class of non-thiol-containing peptidomimetic inhibitors of farnesyltransferase and geranylgeranyltransferase I: combination therapy with the cytotoxic agents cisplatin, Taxol, and gemcitabine. Cancer Res 1999, 59( 19):4919-4926.

\section{Pre-publication history}

The pre-publication history for this paper can be accessed here:

http://www.biomedcentral.com/1471-2407/7/8/prepub 